Article

\title{
Low Level of Colistin Resistance and $m c r$ Genes Presence in Salmonella spp.: Evaluation of Isolates Collected between 2000 and 2020 from Animals and Environment
}

\author{
Fabrizio Bertelloni * (D), Giulia Cagnoli, Barbara Turchi and Valentina Virginia Ebani
}

check for

updates

Citation: Bertelloni, F.; Cagnoli, G.; Turchi, B.; Ebani, V.V. Low Level of Colistin Resistance and $m c r$ Genes Presence in Salmonella spp.: Evaluation of Isolates Collected between 2000 and 2020 from Animals and Environment. Antibiotics 2022, 11, 272. https://doi.org/10.3390/ antibiotics11020272

Academic Editors: Ilias Karaiskos and Jonathan Frye

Received: 30 December 2021 Accepted: 16 February 2022 Published: 19 February 2022

Publisher's Note: MDPI stays neutral with regard to jurisdictional claims in published maps and institutional affiliations.

Copyright: (C) 2022 by the authors. Licensee MDPI, Basel, Switzerland. This article is an open access article distributed under the terms and conditions of the Creative Commons Attribution (CC BY) license (https:// creativecommons.org/licenses/by/ $4.0 /)$.
Department of Veterinary Science, University of Pisa, 56124 Pisa, Italy; g.cagnoli@studenti.unipi.it (G.C.); barbara.turchi@unipi.it (B.T.); valentina.virginia.ebani@unipi.it (V.V.E.)

* Correspondence: fabrizio.bertelloni@unipi.it

\begin{abstract}
Salmonellosis is one of the most important zoonoses in Europe and the world. Human infection may evolve in severe clinical diseases, with the need for hospitalization and antimicrobial treatment. Colistin is now considered an important antimicrobial to treat infections from multidrugresistant Gram-negative bacteria, but the spreading of mobile colistin-resistance $(\mathrm{mcr})$ genes has limited this option. We aimed to evaluate colistin minimum inhibitory concentration and the presence of $\mathrm{mcr}$ ( $\mathrm{mcr}-1$ to $\mathrm{mcr}-9$ ) genes in 236 Salmonella isolates previously collected from different animals and the environment between 2000 and 2020. Overall, 17.79\% of isolates were resistant to colistin; no differences were observed in relation to years of isolation (2000-2005, 2009-2014, and 2015-2020), Salmonella enterica subspecies (enterica, salamae, diarizonae, and houtenae), origin of samples (domestic animals, wildlife, and environment), or animal category (birds, mammals, and reptiles); only recently isolated strains from houseflies showed the most resistance. Few isolates (5.93\%) scored positive for $m c r$ genes, in particular for $m c r-1, m c r-2, m c r-4, m c r-6$, and $m c r-8$; furthermore, only $2.54 \%$ of isolates were $m c r$-positive and colistin-resistant. Detected resistance to colistin was equally distributed among all examined Salmonella isolates and not always related to the presence of $\mathrm{mcr}$ genes.
\end{abstract}

Keywords: Salmonella; colistin resistance; mcr; animals

\section{Introduction}

Colistin is an old antibiotic, discovered in 1947, and belonging to the class of polymyxins. The target of this antimicrobial is the outer membrane lipopolysaccharides (LPS) of Gram-negative bacteria [1]. In human medicine, colistin use has been largely abandoned since the mid-1970s as a consequence of some adverse events, primarily nephrotoxicity and neurotoxicity, combined with the discovery of new antibiotics [2]. In contrast, colistin was largely used in veterinary medicine worldwide to treat infections, mainly from Enterobacteriaceae, in terrestrial and aquatic animals. Furthermore, it was used for decades as a growth promoter in farm animals in many countries; this practice is still allowed in some territories [3]. The increase in antimicrobial resistance led, by the mid-1990s, to the rediscovery of colistin for human therapy as a last-resort antibiotic in multidrug-resistant Gram-negative infections [2,4]. Consequently, policies for the reduction in use of colistin in animals were advanced in many countries, although the resistance to this antimicrobial was not so diffuse [1,5]. Resistance to colistin remained a rare event for years, probably because it is encoded chromosomally and consequently transferred only vertically $[2,5]$.

In 2015, the first plasmid gene able to confer resistance to colistin, $m c r-1$, was detected in Escherichia coli in China [6]. Subsequently, different variants of this gene, from $m c r-2$ to $m c r-10$, and numerous subvariants have been reported [7,8]. Surprisingly, retrospective investigations highlighted the presence of $\mathrm{mcr}$ genes in strains isolated from the 1980s, but particularly in bacteria cultured in the last twenty years [9-11]. However, before 2015, colistin resistance was not considered a serious threat and resistance levels were generally 
low [12]. Starting in 2015, reports of colistin-resistant and mcr-positive bacteria increased; now, these events are reported worldwide in many Gram-negative bacteria [12,13].

Despite E. coli remaining the main bacterial species involved in this phenomenon, colistin resistance and $m c r$-mediated resistance were also reported in Salmonella [14]. Phenotypic resistance to colistin in Salmonella is variable in relation to serotypes, year of isolation, source (humans, animals, food, and environment), and geographic area. However, percentages of resistant strains are generally low, ranging between about $1 \%$ and $12 \%$ [15-18], with some exceptions (40\%) [19]. The gene $m c r-1$ was the most frequently detected in Salmonella, but $m c r-2, m c r-3, m c r-4, m c r-5$, and $m c r-9$ were also detected [20]. Domestic animals were identified as the main reservoir of $m c r$-positive salmonellae and $S$. ser Typhimurium as the most frequent serovar carrying these genes [14,20]. However, detection rate of $m c r$-positive Salmonella strains is generally low [17,18,21], with some exceptions [22]. As reported for other bacteria, the direct relation between the presence of $\mathrm{mcr}$ genes and colistin resistance in Salmonella has not been fully clarified; these genes have also been found in susceptible strains [15], and, frequently, only a small number of resistant strains carry these genes [16-18], suggesting other mechanisms of resistance [2]. In S. enterica, different chromosomally encoded mechanisms were identified as conferring resistance to colistin. In particular, the addition of 4-amino-4-deoxy-L-arabinose (L-Ara4N) and phosphoethanolamine (PEtN) to the phosphate groups of lipid A causes the alteration of the LPS structure; this event alters the primary target of colistin. The arnBCADTEF and pmrCAB operons are responsible for this process; they are up-regulated by the two-component regulatory systems (TCSs) PmrA/PmrB and PhoP/PhoQ. Overactivation of TCSs by external stimuli or by mutations may lead to the hyper-expression of arnBCADTEF and $p m r C A B$. Mutations in $m g r B$, a suppressor gene of the PhoP/PhoQ system, may produce the same result. Deacylation of lipid A, mediated by $p a g L, r p o N$, and ipxM genes, may be another mechanism mediating colistin resistance, although less common in S. enterica than in other bacteria, such as Acinetobacter baumannii. Finally, it has been proposed that alteration of efflux pumps (sapABCDF operon) and porins by cytoplasmic molecules (ydeI/ompD system) can increase bacterial resistance to polymyxins $[2,13,23,24]$.

The aim of this study was to investigate the colistin resistance and presence of $\mathrm{mcr}$ genes ( $m c r-1$ to $m c r-9)$ in Salmonella strains isolated from animals or related environments, including strains cultured from atypical samples (reptiles and wild animals) and belonging to serotypes that are not frequently detected or investigated, collected between 2000 and 2020.

\section{Results}

\subsection{Evaluation of Minimum Inhibitory Concentration (MIC) for Colistin}

Overall, 42/236 (17.79\%) isolates showed resistance to colistin; most of them, 33/236 $(13.98 \%)$, showed an MIC equal to the breakpoint, $4 \mu \mathrm{g} / \mathrm{mL}$. Consequently, only nine (3.81\%) strains had a higher MIC. In particular, one $(0.42 \%)$ isolate had an MIC of $8 \mu \mathrm{g} / \mathrm{mL}$, one $(0.42 \%)$ isolate of $16 \mu \mathrm{g} / \mathrm{mL}$, one $(0.42 \%)$ isolate of $256 \mu \mathrm{g} / \mathrm{mL}$ and six $(2.54 \%)$ isolates had an MIC higher than $256 \mu \mathrm{g} / \mathrm{mL}$.

Considering the years of isolation of the investigated strains and the first report of mor genes in 2015, to evaluate the distribution over time of colistin resistance, isolates were arranged in three groups: salmonellae collected between 2000 and 2005, between 2009 and 2014, and finally, between 2015 and 2020 (no isolates were collected between 2006 and 2008). Percentages of resistant strains collected between 2000-2005 and 2009-2014 were very similar, $15.17 \%(17 / 112)$ and $15.27 \%(11 / 72)$, respectively, and no statistical differences emerged $(p>0.05)$. Although the percentage of resistant salmonellae isolated in the period 2015-2020 was higher, $28.00 \%$ (14/50), this difference was not statistically significant $(p>0.05)$. Table 1 shows detailed data on distribution of MICs over time in examined Salmonella strains. 
Table 1. Distribution of the tested Salmonella strains in relation to minimum inhibitory concentration (MIC) values and years of isolation.

\begin{tabular}{|c|c|c|c|c|c|c|c|c|c|c|c|c|}
\hline \multirow{2}{*}{ Years of Isolation } & \multicolumn{11}{|c|}{ MIC Values $(\mu \mathrm{g} / \mathrm{mL})$} & \multirow{2}{*}{ Total } \\
\hline & $\leq 0.5$ & 1 & 2 & 4 & 8 & 16 & 32 & 64 & 128 & 256 & $>256$ & \\
\hline 2000-2005 & 30 & 26 & 39 & 14 & 0 & 1 & 0 & 0 & 0 & 1 & 1 & 112 \\
\hline 2009-2014 & 16 & 26 & 19 & 10 & 1 & 0 & 0 & 0 & 0 & 0 & 0 & 72 \\
\hline 2015-2020 & 12 & 8 & 16 & 9 & 0 & 0 & 0 & 0 & 0 & 0 & 5 & 50 \\
\hline Total & 58 & 61 & 75 & 33 & 1 & 1 & 0 & 0 & 0 & 1 & 6 & 58 \\
\hline
\end{tabular}

Considering the source of the strains, 174 isolates were from domestic animals, including pets, 51 isolates were from wild animals, including houseflies and crayfish, and 11 isolates were from environmental and feed samples. In detail, 13 isolates were cultured from Arthropoda (housefly and crayfish), 51 from birds, 63 from mammals, and 98 from reptiles. Of strains from domestic animals, $16.67 \%$ (29/174) showed resistance to colistin, whereas $23.53 \%(12 / 51)$ and $9.09 \%(1 / 11)$ of isolates from wild animals and environmental samples were resistant, respectively (Table 2); no statistical differences were observed $(p>0.05)$. Likewise, 38.46\% (5/13), 21.57\% (11/51), 22.22\% (14/63), and 11.22\% (11/98) of Salmonella isolates from Arthropoda, birds, mammals, and reptiles showed resistance to colistin, respectively (Table 3); no statistical differences emerged among strains from birds, mammals, and reptiles $(p>0.05)$, whereas isolates from Arthropoda appeared more resistant than salmonellae from other animals $(p<0.05)$.

Table 2. Distribution of the tested Salmonella strains in relation to minimum inhibitory concentration (MIC) values and origin of samples.

\begin{tabular}{|c|c|c|c|c|c|c|c|c|c|c|c|c|}
\hline & \multicolumn{11}{|c|}{ MIC Values $(\mu \mathrm{g} / \mathrm{mL})$} & \multirow{2}{*}{ Total } \\
\hline & $\leq 0.5$ & 1 & 2 & 4 & 8 & 16 & 32 & 64 & 128 & 256 & $>256$ & \\
\hline Domestic animals & 43 & 48 & 54 & 22 & 1 & 1 & 0 & 0 & 0 & 1 & 4 & 174 \\
\hline Wild animals & 14 & 10 & 15 & 10 & 0 & 0 & 0 & 0 & 0 & 0 & 2 & 51 \\
\hline Environment & 1 & 3 & 6 & 1 & 0 & 0 & 0 & 0 & 0 & 0 & 0 & 11 \\
\hline Total & 58 & 61 & 75 & 33 & 1 & 1 & 0 & 0 & 0 & 1 & 6 & 236 \\
\hline
\end{tabular}

Table 3. Distribution of the tested Salmonella strains in relation to minimum inhibitory concentration (MIC) values and animal categories.

\begin{tabular}{ccccccccccccc}
\hline & \multicolumn{1}{c}{ MIC Values $(\mu \mathrm{g} / \mathbf{m L})$} & \multicolumn{1}{c}{ Total } \\
\cline { 2 - 10 } & $\leq \mathbf{0 . 5}$ & $\mathbf{1}$ & $\mathbf{2}$ & $\mathbf{4}$ & $\mathbf{8}$ & $\mathbf{1 6}$ & $\mathbf{3 2}$ & $\mathbf{6 4}$ & $\mathbf{1 2 8}$ & $\mathbf{2 5 6}$ & $\mathbf{> 2 5 6}$ & 0 \\
\hline Arthropoda & 3 & 1 & 4 & 5 & 0 & 0 & 0 & 0 & 0 & 0 & 0 & 13 \\
Birds & 10 & 16 & 14 & 10 & 1 & 0 & 0 & 0 & 0 & 0 & 0 & 51 \\
Mammals & 14 & 15 & 20 & 8 & 0 & 0 & 0 & 0 & 0 & 0 & 6 & 63 \\
Reptiles & 30 & 26 & 31 & 9 & 0 & 1 & 0 & 0 & 0 & 1 & 0 & 98 \\
Environment/Feed & 1 & 3 & 6 & 1 & 0 & 0 & 0 & 0 & 0 & 0 & 0 & 11 \\
Total & 58 & 61 & 75 & 33 & 1 & 1 & 0 & 0 & 0 & 1 & 6 & 236 \\
\hline
\end{tabular}

All analyzed strains belonged to the species S. enterica. In particular, 202 isolates belonged to subspecies enterica, 7 to subspecies salamae, 9 to subspecies diarizonae, and 14 to subspecies houtenae; finally, 4 strains were in the $\mathrm{R}$ phase. Table 4 shows the distribution of MIC values in relation to Salmonella subspecies. Considering the MIC results, $16.83 \%$ $(34 / 202)$ of $S$. enterica sub. enterica isolates showed resistance, $14.29 \%(1 / 7)$ of $S$. enterica sub. salamae isolates, $22.22 \%$ (2/9) of $S$. enterica sub. diarizonae isolates, and $21.43 \%(3 / 14)$ of $S$. enterica sub. houtenae isolates showed resistance to colistin; $50.00 \%$ of R-phase strains were resistant. No statistical differences emerged among the different subspecies $(p>0.05)$. 
Table 4. Distribution of the tested Salmonella strains in relation to minimum inhibitory concentration (MIC) values and subspecies.

\begin{tabular}{|c|c|c|c|c|c|c|c|c|c|c|c|c|}
\hline \multirow{2}{*}{ Subspecies } & \multicolumn{11}{|c|}{ MIC Values $(\mu \mathrm{g} / \mathrm{mL})$} & \multirow{2}{*}{ Total } \\
\hline & $\leq 0.5$ & 1 & 2 & 4 & 8 & 16 & 32 & 64 & 128 & 256 & $>256$ & \\
\hline enterica & 48 & 59 & 61 & 30 & 1 & 1 & 0 & 0 & 0 & 0 & 2 & 202 \\
\hline salamae & 3 & 0 & 3 & 1 & 0 & 0 & 0 & 0 & 0 & 0 & 0 & 7 \\
\hline diarizonae & 3 & 1 & 3 & 0 & 0 & 0 & 0 & 0 & 0 & 0 & 2 & 9 \\
\hline houtenae & 3 & 1 & 7 & 0 & 0 & 0 & 0 & 0 & 0 & 1 & 2 & 14 \\
\hline $\mathrm{R}$ phase & 1 & 0 & 1 & 2 & 0 & 0 & 0 & 0 & 0 & 0 & 0 & 4 \\
\hline Total & 58 & 61 & 75 & 33 & 1 & 1 & 0 & 0 & 0 & 1 & 6 & 236 \\
\hline
\end{tabular}

A serovar-to-serovar comparison was not feasible because, for most serovars, only one isolate was available. We compared the data relating to the six serovars most frequently detected in human infections in EU between 2015 and 2019: Enteritidis, Typhimurium, Typhimurium monophasic variants, Infantis, Derby, and Newport [25]. As shown in Table 5, $40.00 \%$ of $S$. ser. Enteritidis, $20.69 \%$ (6/29) of $S$. ser. Typhimurium, $14.9 \%(1 / 7)$ of $S$. ser. Typhimurium monophasic variants, $25.00 \%(2 / 8)$ of $S$. ser. Infantis, $12.50 \%(2 / 16)$ of $S$. ser. Derby, and $0.00 \%(0 / 3)$ of $S$. ser. Newport showed resistance to colistin; no statistical differences were observed $(p>0.05)$.

Table 5. Minimum inhibitory concentration (MIC) values obtained for Salmonella serovars most frequently detected in human infections in EU between 2015 and 2019.

\begin{tabular}{|c|c|c|c|c|c|c|c|c|c|c|c|c|}
\hline \multirow{2}{*}{ Serovar } & \multicolumn{11}{|c|}{ MIC Values $(\mu \mathrm{g} / \mathrm{mL})$} & \multirow{2}{*}{ Total } \\
\hline & $\leq 0.5$ & 1 & 2 & 4 & 8 & 16 & 32 & 64 & 128 & 256 & $>256$ & \\
\hline Derby & 4 & 8 & 2 & 1 & 0 & 0 & 0 & 0 & 0 & 0 & 1 & 16 \\
\hline Enteritidis & 0 & 3 & 3 & 3 & 1 & 0 & 0 & 0 & 0 & 0 & 0 & 10 \\
\hline Infantis & 1 & 2 & 3 & 2 & 0 & 0 & 0 & 0 & 0 & 0 & 0 & 8 \\
\hline Newport & 1 & 2 & 0 & 0 & 0 & 0 & 0 & 0 & 0 & 0 & 0 & 3 \\
\hline TMV & 0 & 5 & 1 & 1 & 0 & 0 & 0 & 0 & 0 & 0 & 0 & 7 \\
\hline Typhimurium & 9 & 5 & 9 & 5 & 0 & 0 & 0 & 0 & 0 & 0 & 1 & 29 \\
\hline
\end{tabular}

Legend: TMV = Typhimurium monophasic variant.

\subsection{Molecular Detection of mor Genes}

None of the isolates were positive for $m c r-3, m c r-5, m c r-7$, or $m c r-9$ genes. The most detected gene was $m c r-2$, with $7 / 236$ (2.96\%) positive isolates, followed by $m c r-4$, with $4 / 236$ (1.69\%) positive isolates, and $m c r-1$ and $m c r-8$, with $2 / 236(0.84 \%)$ positive isolates each; only $1 / 236(0.42 \%)$ scored positive for $m c r-6$. Overall, 14/236 (5.93\%) isolates were positive for $\mathrm{mcr}$ genes; only two isolates scored positive for more than one gene. Six isolates were collected in 2019 from different specimens and showed phenotypic resistance to colistin. Eight Salmonella strains, collected in 2002 from reptiles, showed susceptibility to colistin, although they were positive for the investigated resistance genes. Table 6 shows detailed information about $m c r$-positive strains. 
Table 6. Detailed information about the mor-positive Salmonella isolates.

\begin{tabular}{|c|c|c|c|c|c|c|c|c|c|c|c|}
\hline Isolate & Subspecies & Serovar & Animal & Sample & Year & $\begin{array}{c}\text { MIC } \\
(\mu \mathrm{g} / \mathrm{mL})\end{array}$ & $m c r-1$ & $m c r-2$ & $m c r-4$ & $m c r-6$ & $m c r-8$ \\
\hline S356 & houtenae & $1,40: z_{4}, z_{23}:-$ & Donkey & Organs & 2019 & $>256$ & - & + & - & - & - \\
\hline S358 & houtenae & $1,40: z_{4}, z_{23}:-$ & Sheep & Organs & 2019 & $>256$ & - & + & - & - & - \\
\hline S374 & enterica & Napoli & Housefly & & 2019 & 4 & - & + & + & - & - \\
\hline S375 & & R phase & Housefly & & 2019 & 4 & - & - & + & - & - \\
\hline S378 & & $\mathrm{R}$ phase & Housefly & & 2019 & 4 & - & - & + & - & - \\
\hline S386 & diarizonae & 50:r:1,5,7 & Wild boar & Feces & 2019 & $>256$ & + & - & - & - & - \\
\hline $\mathrm{R} 43$ & enterica & Trimndon & Reptile & Feces & 2002 & $\leq 0.5$ & - & - & - & + & - \\
\hline R108 & enterica & Memphis & Reptile & Feces & 2002 & $\leq 0.5$ & - & + & - & - & - \\
\hline R164 & houtenae & $44: z_{4}, z_{23}:-$ & Reptile & Feces & 2002 & 2 & - & - & - & - & + \\
\hline R161 & houtenae & $44: z_{4}, z_{23}:-$ & Reptile & Feces & 2002 & 2 & - & + & - & - & - \\
\hline R173 & enterica & Senftenberg & Reptile & Feces & 2002 & $\leq 0.5$ & - & - & - & - & + \\
\hline R300 & diarizonae & $50: z: Z_{52}$ & Reptile & Feces & 2002 & 1 & + & - & + & - & - \\
\hline R112 & houtenae & $18: z_{36}, z_{23}:-$ & Reptile & Feces & 2002 & $\leq 0.5$ & - & + & - & - & - \\
\hline R126 & diarizonae & $48: z_{4}, z_{23}:-$ & Reptile & Feces & 2002 & 2 & - & + & - & - & - \\
\hline \multicolumn{7}{|c|}{ Total } & 2 & 7 & 4 & 1 & 2 \\
\hline
\end{tabular}

\section{Discussion}

Salmonella is one of the most important food-borne zoonotic pathogens worldwide. In Europe, salmonellosis is the second most prevalent zoonosis considering the total number of confirmed cases and the most prevalent considering the total number of outbreaks. In 2019, in EU, Salmonella was responsible for 87,923 confirmed human cases, 16,628 hospitalizations, and 140 deaths [25]. In Europe, antimicrobial resistance, mainly multidrug resistance, was generally lower in Salmonella than in other Enterobacteriaceae, with differences related to serotype and geographic territory [26]. Colistin was recently reintroduced in human therapy and it is now considered a critically important antimicrobial [27]. For this reason, the discovery of mobile genes conferring colistin resistance caused many concerns. These genes were more commonly observed among E. coli strains, but they were also detected in other Gram-negative bacteria, such as Salmonella [28].

The number of studies on phenotypic colistin resistance in Salmonella is limited. Past works were usually based on the disk diffusion test, a method not suitable for colistin resistance detection [1]; on the other hand, recent investigations usually focused on $m c r$-positive strains. In our study, the percentage of colistin-resistant strains was $17.79 \%$, which is slightly higher than the data reported in recent literature. Recent surveys registered percentages of colistin-resistant Salmonella strains ranging between $1 \%$ and $12 \%[15,17,18,29,30]$. These differences may be due to many factors: source, geographic area, and serotype. It is interesting to note that no differences were observed in relation to years of isolation, suggesting a basal level of diffused resistance. Unfortunately, our study suffers from the heterogeneity of samples from which Salmonella isolates were cultured; thus, it was not possible to draw a conclusion in terms of monitoring over time. However, this limitation may also represent a strength of the study, showing a condition largely spread among the Salmonella genus and not restricted to strains coming from a particular matrix. To underline this hypothesis, no differences were observed among strains from wild animals, domestic animals, or environment, or from different animal categories: birds, mammals, and reptiles. Salmonella isolates from houseflies (Musca domestica) were statistically the most resistant strains. Considering the behavior of houseflies, the obtained results may suggest that these insects might be involved in the diffusion of colistin-resistant salmonellae.

Most of the available studies in the literature focused on a subset of serovars, the ones mainly involved in human and animal salmonellosis, such as Typhimurium and Enteritidis [14,16,20]. Few data are available on colistin resistance in Salmonella belonging to uncommon serovars or subspecies [31]. In our investigation, more than 70 different serovars, belonging to four subspecies, were included. In relation to phenotypic colistin 
resistance, no statistical differences were observed among the subspecies. Furthermore, no statistical differences emerged among the six serovars most frequently detected in human infections in EU between 2015 and 2019 [25]. These findings support the hypothesis of a diffused resistance among tested salmonellae. Moreover, our results show that the less investigated serovars may also be involved in the phenomenon of colistin resistance.

Regarding mobile colistin-resistance genes, few isolates scored positive (5.93\%) for one or more genes. This finding is in agreement with other studies reporting a percentage of mcr-positive Salmonella strains ranging between $0.6 \%$ and 3.3\% [15,17-19,29]. The slightly higher positivity detected in our survey may be related to the extended set of investigated genes. Our data confirm the low circulation of these genes in the Salmonella genus compared to other Enterobacteriaceae, especially E. coli. E. coli seems to be the primary species having mor genes [9,28,32], also confirmed by the high prevalence of $m c r$-positive E. coli strains $(44.6 \%)$ isolated from wild boar from the same geographic area [33].

The low detection rate of $\mathrm{mcr}$ genes compared to found phenotypic resistance suggests the low involvement of these genes in colistin resistance in Salmonella, as also supposed by other authors $[17,29]$. Detected resistance may be related to other chromosome-related mechanisms. From this point of view, the TCSs ( $p m r A / p m r B$ and $p h o P / p h o Q)$ play a key role in colistin resistance in Salmonella. Mutations occurring in these genes or in their regulatory genes, such as $m g r B$ for PhoP/Q, lead to the modification of lipid A and, consequently, the alteration of the colistin target $[2,13,24]$. Up-regulation of TCSs may also be the consequence of environmental stimuli, including low $\mathrm{Mg}^{2+}$ concentrations [2]. For this reason, cation-adjusted Mueller-Hinton medium was employed in MIC tests, as recommended by CLSI [34]. Other resistance mechanisms reported in Salmonella are related to efflux pumps and porins, but they seem to play a secondary role in colistin resistance in these bacteria [1].

Only 6/14 mcr-positive isolates were resistant to colistin. All mcr-positive and colistinsusceptible strains were from reptiles sampled in 2002. The gene $m c r-1$ was detected for the first time in E. coli in 2015 [6]. However, studies performed since 2015 have also shown the presence of this gene in previously obtained isolates [9], including Salmonella strains [14,20]. Currently, the exact relation between the presence of $\mathrm{mcr}$ genes and phenotypic resistance to colistin is controversial and far from being fully understood. In most studies, only colistinresistant strains were screened for $m c r$ and this aspect may cause a lack of information. Recent investigations also showed the abundant presence of these genes in susceptible bacteria [35]; furthermore, some $m c r$ variants are unable to confer colistin resistance [31]. The obtained results highlighted the importance of carrying out both phenotypic and genotypic analyses to investigate the antimicrobial resistance.

The present research, which focused on the resistance to colistin in Salmonella strains cultured from different sources, suffers from some limitations. It would be useful to investigate if colistin-resistant and $m c r$-positive strains are also resistant to other antibiotics and whether they harbor other resistant genes, particularly at the plasmid level. Furthermore, we investigated only the involvement of $\mathrm{mcr}$ genes in colistin resistance. As reported above, other chromosomally related mechanisms induce resistance to colistin; the study of these systems may explain some resistances that were phenotypically detected.

\section{Materials and Methods}

\subsection{Salmonella Strains Included in the Study}

This investigation was conducted on 236 Salmonella spp. strains preserved in the biobank of the Laboratory of Infectious Disease of the Department of Veterinary Sciences, University of Pisa, Italy. All strains were collected during routine investigations or specific research. Most of the isolates came from apparently healthy animals. The strains were selected based on their pulsotype profile and/or taking into consideration epidemiological information. All strains were isolated from feces or organs of various domestic or wild animals (mammals, birds, reptiles, and arthropods), with the exception of 11 strains coming from environmental or feed samples collected at animal farms. Supplementary Table S1 
shows information for each strain related to the type of sample, isolation year, species, subspecies, and serotype.

\subsection{Evaluation of Minimum Inhibitory Concentration for Colistin}

The broth microdilution method was employed for evaluation of minimum inhibitory concentrations (MICs) of colistin. The protocol described by CLSI was adopted [34]; cationadjusted Mueller-Hinton (MH) broth (Oxoid, Milan, Italy) was used and colistin sulfate (CARLO ERBA Reagents, Cornaredo, Italy) was diluted 2-fold from 256 to $0.5 \mu \mathrm{g} / \mathrm{mL}$. Isolates showing an MIC $>2 \mu \mathrm{g} / \mathrm{mL}$ were recorded as resistant [36].

\subsection{Molecular Detection of mor Genes}

DNA was extracted from overnight agar cultures with a commercial kit, DNA Plus Kits (Zymo Research, Irvine, CA, USA), following the manufacturer's guidelines.

Two multiplex PCR assays were employed: the first for the detection of genes $m c r-1$, $m c r-2, m c r-3, m c r-4$, and $m c r-5$; and the second to detect $m c r-6, m c r-7, m c r-8$, and $m c r-9$ genes. The assays were executed using primers and protocols published elsewhere $[37,38]$ and are shown in Table 7 . PCR reactions were carried out in a volume of $50 \mu \mathrm{L}$ including $25 \mu \mathrm{L}$ EconoTaq PLUS GREEN 2X Master Mixes (Lucigen Corporation, Middleton, WI, USA), $0.5 \mu \mathrm{L}$ of each primer (10 $\mu \mathrm{M}$ concentration), $3 \mu \mathrm{L}$ of template DNA, and PCR-grade water to reach the final volume.

Table 7. Primers and protocols employed in PCR assays.

\begin{tabular}{|c|c|c|c|c|c|c|}
\hline & $\begin{array}{l}\text { Target } \\
\text { Gene }\end{array}$ & Primer Name & Sequence $\left(5^{\prime}-3^{\prime}\right)$ & $\begin{array}{l}\text { Expected } \\
\text { Size (bp) }\end{array}$ & Protocols & References \\
\hline Multiplex 1 & $\begin{array}{l}m c r-1 \\
m c r-2 \\
m c r-3 \\
m c r-4 \\
m c r-5\end{array}$ & $\begin{array}{l}\text { mcr1_320bp_fw } \\
\text { mcr1_320bp_rev } \\
\text { mcr2_700bp_fw } \\
\text { mcr2_700bp_rev } \\
\text { mcr3_900bp_fw } \\
\text { mcr3_900bp_rev } \\
\text { mcr4_1100bp_fw } \\
\text { mcr4_1100bp_rev } \\
\text { MCR5_fw } \\
\text { MCR5_rev }\end{array}$ & $\begin{array}{c}\text { AGTCCGTTTGTTCTTGTGGC } \\
\text { AGATCCTTGGTCTCGGCTTG } \\
\text { CAAGTGTGTTGGTCGCAGTT } \\
\text { TCTAGCCCGACAAGCATACC } \\
\text { AAATAAAAATTGTTCCGCTTATG } \\
\text { AATGGAGATCCCCGTTTTT } \\
\text { TCACTTTCATCACTGCGTTG } \\
\text { TTGGTCCATGACTACCAATG } \\
\text { ATGCGGTTGTCTGCATTTATC } \\
\text { TCATTGTGGTTGTCCTTTTCTG }\end{array}$ & $\begin{array}{l}320 \\
715 \\
929 \\
1116 \\
1644\end{array}$ & $\begin{array}{l}\text { Initial denaturation at } \\
95^{\circ} \mathrm{C} \text { for } 10 \mathrm{~min}, \\
25 \text { cycles: denaturation at } \\
95^{\circ} \mathrm{C} \text { for } 30 \mathrm{~s}, \\
\text { annealing at } 58^{\circ} \mathrm{C} \text { for } 90 \mathrm{~s}, \\
\text { elongation at } 72{ }^{\circ} \mathrm{C} \text { for } 60 \mathrm{~s} \text {, } \\
\text { Final elongation at } 72{ }^{\circ} \mathrm{C} \\
\text { for } 10 \text { min. }\end{array}$ & [38] \\
\hline Multiplex 2 & $\begin{array}{l}m c r-6 \\
m c r-7 \\
m c r-8 \\
m c r-9\end{array}$ & $\begin{array}{l}\text { mcr-6_mp_fw } \\
\text { mcr-6_mp_rev } \\
\text { mcr-7_mp_fw } \\
\text { mcr-7_mp_rev } \\
\text { mcr-8_mp_fw } \\
\text { mcr-8_mp_rev } \\
\text { mcr-9_mp_fw } \\
\text { mcr-9_mp_rev }\end{array}$ & $\begin{array}{c}\text { AGCTATGTCAATCCCGTGAT } \\
\text { ATTGGCTAGGTTGTCAATC } \\
\text { GCCCTTCTTTTCGTTGTT } \\
\text { GGTTGGTCTCTTTCTCGT } \\
\text { TCAACAATTCTACAAAGCGTG } \\
\text { AATGCTGCGCGAATGAAG } \\
\text { TTCCCTTTGTTCTGGTTG } \\
\text { GCAGGTAATAAGTCGGTC }\end{array}$ & $\begin{array}{l}252 \\
551 \\
856\end{array}$ & $\begin{array}{l}\text { Initial denaturation at } 95^{\circ} \mathrm{C} \\
\text { for } 10 \text { min, } \\
30 \text { cycles: denaturation at } \\
95^{\circ} \mathrm{C} \text { for } 30 \mathrm{~s}, \\
\text { annealing at } 55^{\circ} \mathrm{C} \text { for } 30 \mathrm{~s}, \\
\text { elongation at } 72^{\circ} \mathrm{C} \text { for } 60 \mathrm{~s} \text {, } \\
\text { Final elongation step at } \\
72^{\circ} \mathrm{C} \text { for } 10 \text { min. }\end{array}$ & [37] \\
\hline
\end{tabular}

\subsection{Statistical Analyses}

Chi-square $\left(\mathrm{X}^{2}\right)$ and Fisher $(\mathrm{F})$ tests were used to evaluate the obtained data. In particular, statistical tests were used to compare distribution of resistant strains and positivity to $m \mathrm{cr}$ genes in relation to: year of isolation, source of isolates, Salmonella subspecies, and serovars. The statistical significance threshold was set at a $p$-value $\leq 0.05$.

\section{Conclusions}

In the present study, we focused on the resistance to colistin in Salmonella strains isolated and collected over the last twenty years. No relevant differences emerged among the investigated isolates, suggesting a broad resistance in strains from different sources belonging to different serovars and isolated in different years. Phenotypic resistance was not always associated with $\mathrm{mcr}$ genes, confirming that this rising issue marginally involves Salmonella strains. The results of the resistance of the studied isolates to other antimicrobials have been reported in previous surveys. However, the present investigation 
may be improved by further data about other possible genetic mechanisms responsible for colistin resistance, as suggested by some authors who assumed that chromosomally related mechanisms are involved $[2,13,24]$. Programs of antibiotic-resistance monitoring should include Salmonella of uncommon serovars and isolated from atypical hosts to obtain more real and valuable information.

Supplementary Materials: The following are available online at https:/ / www.mdpi.com/article/ 10.3390/antibiotics11020272/s1, Table S1: Detailed information about analyzed Salmonella isolates.

Author Contributions: Conceptualization, F.B.; formal analysis, F.B. and G.C.; investigation, F.B. and G.C.; resources, V.V.E.; data curation, F.B. and B.T.; writing-original draft preparation, F.B. and B.T.; writing-review and editing, F.B. and V.V.E.; supervision, V.V.E.; funding acquisition, V.V.E. All authors have read and agreed to the published version of the manuscript.

Funding: This research was funded by University of Pisa, Fondi di Ateneo.

Data Availability Statement: The data presented in this study are available within the article and Supplementary Material.

Conflicts of Interest: The authors declare no conflict of interest.

\section{References}

1. Poirel, L.; Jayol, A.; Nordmanna, P. Polymyxins: Antibacterial activity, susceptibility testing, and resistance mechanisms encoded by plasmids or chromosomes. Clin. Microbiol. Rev. 2017, 30, 557-596. [CrossRef] [PubMed]

2. $\quad$ El-Sayed Ahmed, M.A.E.G.; Zhong, L.L.; Shen, C.; Yang, Y.; Doi, Y.; Tian, G.B. Colistin and its role in the Era of antibiotic resistance: An extended review (2000-2019). Emerg. Microbes Infect. 2020, 9, 868-885. [CrossRef] [PubMed]

3. Kempf, I.; Jouy, E.; Chauvin, C. Colistin use and colistin resistance in bacteria from animals. Int. J. Antimicrob. Agents 2016, 48, 598-606. [CrossRef] [PubMed]

4. Falagas, M.E.; Kasiakou, S.K. Colistin: The Revival of Polymyxins for the Management of Multidrug-Resistant Gram-Negative Bacterial Infections. Clin. Infect. Dis. 2005, 40, 1333-1341. [CrossRef] [PubMed]

5. Venter, H.; Henningsen, M.L.; Begg, S.L. Antimicrobial resistance in healthcare, agriculture and the environment: The biochemistry behind the headlines. Essays Biochem. 2017, 61, 1-10. [CrossRef]

6. Liu, Y.Y.; Wang, Y.; Walsh, T.R.; Yi, L.X.; Zhang, R.; Spencer, J.; Doi, Y.; Tian, G.; Dong, B.; Huang, X.; et al. Emergence of plasmid-mediated colistin resistance mechanism MCR-1 in animals and human beings in China: A microbiological and molecular biological study. Lancet Infect. Dis. 2016, 16, 161-168. [CrossRef]

7. Partridge, S.R.; Di Pilato, V.; Doi, Y.; Feldgarden, M.; Haft, D.H.; Klimke, W.; Kumar-Singh, S.; Liu, J.H.; Malhotra-Kumar, S.; Prasad, A.; et al. Proposal for assignment of allele numbers for mobile colistin resistance (mcr) genes. J. Antimicrob. Chemother. 2018, 73, 2625-2630. [CrossRef] [PubMed]

8. Shen, Y.; Zhang, R.; Schwarz, S.; Wu, C.; Shen, J.; Walsh, T.R.; Wang, Y. Farm animals and aquaculture: Significant reservoirs of mobile colistin resistance genes. Environ. Microbiol. 2020, 22, 2469-2484. [CrossRef]

9. Nang, S.C.; Li, J.; Velkov, T. The rise and spread of mor plasmid-mediated polymyxin resistance. Crit. Rev. Microbiol. 2019, 45, 131-161. [CrossRef]

10. Macori, G.; Nguyen, S.V.; Naithani, A.; Hurley, D.; Bai, L.; Garch, F.E.; Woehrlé, F.; Miossec, C.; Roques, B.; O'gaora, P.; et al. Characterisation of early positive mcr-1 resistance gene and plasmidome in escherichia coli pathogenic strains associated with variable phylogroups under colistin selection. Antibiotics 2021, 10, 1041. [CrossRef]

11. Fan, R.; Li, C.; Duan, R.; Qin, S.; Liang, J.; Xiao, M.; Lv, D.; Jing, H.; Wang, X. Retrospective Screening and Analysis of mcr-1 and blaNDM in Gram-Negative Bacteria in China, 2010-2019. Front. Microbiol. 2020, 11, 121. [CrossRef] [PubMed]

12. Gharaibeh, M.H.; Shatnawi, S.Q. An overview of colistin resistance, mobilized colistin resistance genes dissemination, global responses, and the alternatives to colistin: A review. Vet. World 2019, 12, 1735. [CrossRef] [PubMed]

13. Hamel, M.; Rolain, J.M.; Baron, S.A. The History of Colistin Resistance Mechanisms in Bacteria: Progress and Challenges. Microorganisms 2021, 9, 442. [CrossRef] [PubMed]

14. Lima, T.; Domingues, S.; DaSilva, G. Plasmid-mediated colistin resistance in salmonella enterica: A review. Microorganism 2019, 7, 55. [CrossRef] [PubMed]

15. Pungpian, C.; Lee, S.; Trongjit, S.; Sinwat, N.; Angkititrakul, S.; Prathan, R.; Srisanga, S.; Chuanchuen, R. Colistin resistance and plasmid-mediated mcr genes in Escherichia coli and Salmonella isolated from pigs, pig carcass and pork in Thailand, Lao PDR and Cambodia border provinces. J. Vet. Sci. 2021, 22, 1-15. [CrossRef] [PubMed]

16. Sevilla, E.; Vico, J.P.; Delgado-Blas, J.F.; González-Zorn, B.; Marín, C.M.; Uruén, C.; Martín-Burriel, I.; Bolea, R.; Mainar-Jaime, R.C. Resistance to colistin and production of extended-spectrum $\beta$-lactamases and/or AmpC enzymes in Salmonella isolates collected from healthy pigs in Northwest Spain in two periods: 2008-2009 and 2018. Int. J. Food Microbiol. 2021, 338, 108967. [CrossRef] [PubMed] 
17. Carnevali, C.; Morganti, M.; Scaltriti, E.; Bolzoni, L.; Pongolini, S.; Casadei, G. Occurrence of mcr-1 in Colistin-Resistant Salmonella enterica Isolates Recovered from Humans and Animals in Italy, 2012 to 2015. Antimicrob. Agents Chemother. 2016, 60, 7532. [CrossRef]

18. Garcia-Graells, C.; De Keersmaecker, S.C.J.; Vanneste, K.; Pochet, B.; Vermeersch, K.; Roosens, N.; Dierick, K.; Botteldoorn, N. Detection of Plasmid-Mediated Colistin Resistance, mcr-1 and mcr-2 Genes, in Salmonella spp. Isolated from Food at Retail in Belgium from 2012 to 2015. Foodborne Pathog. Dis. 2018, 15, 114-117. [CrossRef]

19. Luk-in, S.; Chatsuwan, T.; Kueakulpattana, N.; Rirerm, U.; Wannigama, D.L.; Plongla, R.; Lawung, R.; Pulsrikarn, C.; Chantaroj, S.; Chaichana, P.; et al. Occurrence of mcr-mediated colistin resistance in Salmonella clinical isolates in Thailand. Sci. Rep. 2021, 11, 14170. [CrossRef]

20. Portes, A.B.; Rodrigues, G.; Leitão, M.P.; Ferrari, R.; Conte Junior, C.A.; Panzenhagen, P. Global distribution of plasmid-mediated colistin resistance mcr gene in Salmonella: A systematic review. J. Appl. Microbiol. 2021, 132, 872-889. [CrossRef] [PubMed]

21. Arnott, A.; Wang, Q.; Bachmann, N.; Sadsad, R.; Biswas, C.; Sotomayor, C.; Howard, P.; Rockett, R.; Wiklendt, A.; Iredell, J.R.; et al. Multidrug-Resistant Salmonellaenterica 4,[5],12:i:- Sequence Type 34, New South Wales, Australia, 2016-2017. Emerg. Infect. Dis. 2018, 24, 751. [CrossRef] [PubMed]

22. Yi, L.; Wang, J.; Gao, Y.; Liu, Y.; Doi, Y.; Wu, R.; Zeng, Z.; Liang, Z.; Liu, J.H. mcr-1-Harboring Salmonella enterica Serovar Typhimurium Sequence Type 34 in Pigs, China. Emerg. Infect. Dis. 2017, 23, 291. [CrossRef] [PubMed]

23. Pilonieta, M.C.; Erickson, K.D.; Ernst, R.K.; Detweiler, C.S. A Protein Important for Antimicrobial Peptide Resistance, YdeI/OmdA, Is in the Periplasm and Interacts with OmpD/NmpC. J. Bacteriol. 2009, 191, 7243. [CrossRef] [PubMed]

24. Baron, S.; Hadjadj, L.; Rolain, J.M.; Olaitan, A.O. Molecular mechanisms of polymyxin resistance: Knowns and unknowns. Int. J. Antimicrob. Agents 2016, 48, 583-591. [PubMed]

25. EFSA, (European Food Safety Authority); ECDC, (European Centre for Disease Prevention and Control). The European Union One Health 2019 Zoonoses Report. EFSA J. 2021, 19, 6406.

26. EFSA, (European Food Safety Authority); ECDC, (European Centre for Disease Prevention and Control). The European Union Summary Report on Antimicrobial Resistance in zoonotic and indicator bacteria from humans, animals and food in $2018 / 2019$. EFSA J. 2021, 19, 179.

27. WHO (World Health Organization-Advisory Group on Integrated Surveillance of Antimicrobial Resistance). Critically Important Antimicrobials for Human Medicine, 6th Revision 2018; World Health Organization: Geneva, Switzerland, 2019.

28. Khondker, A.; Rheinstädter, M.C. How do bacterial membranes resist polymyxin antibiotics? Commun. Biol. 2020, 3, 77. [CrossRef] [PubMed]

29. Moreno, L.Z.; Gomes, V.T.M.; Moreira, J.; de Oliveira, C.H.; Peres, B.P.; Silva, A.P.S.; Thakur, S.; La Ragione, R.M.; Moreno, A.M. First report of mcr-1-harboring Salmonella enterica serovar Schwarzengrund isolated from poultry meat in Brazil. Diagn. Microbiol. Infect. Dis. 2019, 93, 376-379. [CrossRef] [PubMed]

30. Li, X.P.; Fang, L.X.; Song, J.Q.; Xia, J.; Huo, W.; Fang, J.T.; Liao, X.P.; Liu, Y.H.; Feng, Y.; Sun, J. Clonal spread of mcr-1 in PMQR-carrying ST34 Salmonella isolates from animals in China. Sci. Rep. 2016, 6, 38511. [CrossRef]

31. Tyso, G.H.; Li, C.; Hsu, C.H.; Ayers, S.; Borenstein, S.; Mukherjee, S.; Tran, T.T.; McDermot, P.F.; Zhao, S. The mcr-9 gene of salmonella and escherichia coli is not associated with colistin resistance in the United States. Antimicrob. Agents Chemother. 2020, 64, e00573-20.

32. Elbediwi, M.; Li, Y.; Paudyal, N.; Pan, H.; Li, X.; Xie, S.; Rajkovic, A.; Feng, Y.; Fang, W.; Rankin, S.C.; et al. Global burden of colistin-resistant bacteria: Mobilized colistin resistance genes study (1980-2018). Microorganisms 2019, 7, 461. [CrossRef] [PubMed]

33. Cilia, G.; Turchi, B.; Fratini, F.; Ebani, V.V.; Turini, L.; Cerri, D.; Bertelloni, F. Phenotypic and genotypic resistance to colistin in E. coli isolated from wild boar (Sus scrofa) hunted in Italy. Eur. J. Wildl. Res. 2021, 67, 1-7. [CrossRef]

34. CLSI (Clinical and Laboratory Standards Institute). M07-A10 Methods for Dilution Antimicrobial Susceptibility Tests for Bacteria That Grow Aerobically; Approved Standard, 10th ed.; CLSI Document M07-A10; Clinical and Laboratory Standards Institute: Wayne, PA, USA, 2015.

35. Aguirre, L.; Vidal, A.; Seminati, C.; Tello, M.; Redondo, N.; Darwich, L.; Martín, M. Antimicrobial resistance profile and prevalence of extended-spectrum beta-lactamases (ESBL), AmpC beta-lactamases and colistin resistance (mcr) genes in Escherichia coli from swine between 1999 and 2018. Porc. Health Manag. 2020, 6, 8. [CrossRef]

36. EUCAST, (The European Committee on Antimicrobial Susceptibility Testing). Breakpoint Tables for Interpretation of MICs and Zone Diameters; Version 10.0; The European Committee on Antimicrobial Susceptibility Testing: Basel, Switzerland, 2020.

37. Borowiak, M.; Baumann, B.; Fischer, J.; Thomas, K.; Deneke, C.; Hammerl, J.A.; Szabo, I.; Malorny, B. Development of a Novel mcr-6 to mcr-9 Multiplex PCR and Assessment of mcr-1 to mcr-9 Occurrence in Colistin-Resistant Salmonella enterica Isolates From Environment, Feed, Animals and Food (2011-2018) in Germany. Front. Microbiol. 2020, 11, 80. [CrossRef] [PubMed]

38. Rebelo, A.R.; Bortolaia, V.; Kjeldgaard, J.S.; Pedersen, S.K.; Leekitcharoenphon, P.; Hansen, I.M.; Guerra, B.; Malorny, B.; Borowiak, M.; Hammerl, J.A.; et al. Multiplex PCR for detection of plasmid-mediated colistin resistance determinants, mcr-1, mcr-2, mcr-3, mcr-4 and mcr-5 for surveillance purposes. Eurosurveillance 2018, 23, 17-00672. [CrossRef] 